\title{
ENDOWMENT EFFECT IN LATIN AMERICA: EXPERIMENTAL EVIDENCE
}

\author{
Enrique Manzur \\ Universidad de Chile, Facultad de Economía y Negocios \\ e-mail: emanzur@fen.uchile.cl \\ Sergio Olavarrieta \\ Universidad de Chile, Facultad de Economía y Negocios \\ e-mail: solavar@fen.uchile.cl \\ Pedro Hidalgo \\ Universidad de Chile, Facultad de Economía y Negocios \\ e-mail: phidalgo@fen.uchile.cl \\ Pablo Farías \\ Universidad de Chile, Facultad de Economía y Negocios \\ e-mail:pfarias@fen.uchile.cl
}

\begin{abstract}
Authors from several disciplines -decision sciences, management, marketing, behavioral economics- have documented the existence of anomalies to the standard rational model of human behavior. Among several anomalies, the endowment effect is a key finding of this previous research. Few studies have explored the endowment effect in developing countries. This study reports the results of an experiment conducted in Chile to empirically analyze the endowment effect. Findings are consistent with previous international evidence suggesting the ownership itself produces value to consumers (and decision makers). Implications for marketing, management, business education and policy making practices are briefly presented.
\end{abstract}

Key words: Endowment effects, quasi rational behaviour, choice, consumer behaviour.

\section{RESUMEN}

Autores de diferentes disciplinas - ciencias decisionales, management, marketing, economía del comportamiento- han documentado la existencia de anomalías al modelo estándar racional de comportamiento humano utilizado normalmente en modelos económicos. Entre estas varias anomalías el efecto dotación ha sido uno de los más significativos descubrimientos en estudios previos. Pocos estudios han examinado esta anomlía en países en desarrollo, siendo un fenómeno más reportado en países de mayor desarrollo económico. Este studio reporta los resultados. De un estudio experimental conducido en Chile, que analiza empíricamente el efecto dotación, siguiendo la literatura existente. Los resultados son consistentes con la evidencia previa internacional sugiriendo que la posesión en sí misma produce valor a los personas (y consumidores). Se derivan y presentan brevemente implicancias de estos resultados para marketing, management, educación en negocios, y políticas publicas.

Palabras clave: Efecto dotación, comportamiento cuasi racional, decisión, conducta del consumidor 


\section{INTRODUCTION}

Over recent years, particularly after the recent world financial crisis, researchers in economics, decision sciences, business disciplines and psychology (among others) are paying more attention to the developments in behavioral economics, non-rational or quasi-rational behavior, and have a more critical view of the perfect rational model of man and economic theories using "naïve" beliefs about men and human behaviour. Ariely, Kahneman, Thaler, Simon and others have largely researched the subject finding relevant and substantial evidence in favour of a more complex model of human behaviour. These findings might be very important for management and marketing practices, for financial services and the regulation of financial markets, and for public policy design. Even dating decisions might be affected by this kind of behavior (Hitsch, Hortacsu \&Ariely 2010). Despite the growing attention this quasi-rational perspective of man is attracting in the developed world, Latin American business and economics researchers have done little work to study rationality anomalies in our countries.

In particular, the presence of endowment effects is one of the most important findings of this stream of research. Endowment effects are present when ownership by itself affects choice and behavior. For example, if you own some old snickers you may value them in USD $\$ 50$, closer to the brand new price, however no one -but youwould buy these old snickers from you for more than USD\$10, one fifth of what you are asking.

Rational assumptions of human behavior indicate that people should not have such strong different valuations of a same product, service or activity. According to the expected-utility theory, preferences for final states of endowment are assumed to be stable over variations of initial endowment. However, the empirical evidence from developed countries suggests that this assumption does not always apply. People generally demand more money as compensation for giving up an object than they are willing to pay in order to obtain the same object (Thaler 1980). This finding has been termed the endowment effect. If consumers, managers, and the public in general, experience such effects, marketers, strategists and policy makers should consider the effects of such effect for their business decisions and economic and public policies. Classical selling techniques like "please hold this product in your hand" will be theoretically supported by the presence of endowment effects (Wolf, Arkes and Muhanna 2008).

Despite the general evidence supporting endowment effects, there are other studies that find evidence against it (e.g., Hanemann, 1991; Plott y Zeiler, 2005; Shogren et al., 1994). Few studies have explored the endowment effect in developing countries and to the best of our knowledge, this is the first work in Latin America to empirically analyse the endowment effect in an experimental setting and responds several calls for more research on business in the region (Nicholls-Nixon et al 2011; Fastoso \& Whitelock 2011; Olavarrieta \& Villena 2014). Additionally, previous studies have found differences in the endowement effect between American, European and Japanese samples, suggesting cultural differences (Maddux et al 2010).

\section{THEORY}

According to Bernoulli (1738), agents (e.g., consumers, investors, managers) value choices as wealth states, and order them according to the expected utility of these different states. Accordingly, a major assumption is that initial endowments do 
not intervene in agents' preferences and choices (Kahneman, 2003a). Nevertheless, empirical studies show that marginal substitution rates between one good and another (i.e., preference) is noticeable affected by initial endowments (Kahneman et al., 1991). These effects are "endowment effects".

Endowment effects can be tangibly observed when agents ask for a higher price to sell a good than they are willing to offer for it when they are buying (Thaler, 1980). The endowment effect can be measured as the different between the money one is willing to accept for selling a good and the money a buyer is willing to pay to purchase it (Camerer, 2000; Knetsch \& Sinden, 1984; Thaler, 1987). In other words, a good (product, service) is more valued when it belongs to the existing person's endowment than when it is not part of it. These ideas are against the reigning expected utility theory in economics, that suggests that the value of a good should be the same being part of the endowment or not.

Thaler (1980) is one of the first to formalize the endowment effect, and after him several researchers have advanced and tested the presence of this effect (Knetsch, 1989; Kahneman et al., 1990; List, 2004; Huck et al., 2005; Nayakankuppam \& Mishra, 2005; Tom et al., 2007). Endowment effects are present in many product and service settings: pens, mugs, chocolates, wines, binoculars, soft drinks, sandwiches, movies tickets, sports tickets, home delivery, health services, lotteries, waste disposal, etc. (Novemsky \& Kahneman, 2005; Ryan \& Ubach, 2003; Simonson \& Drolet, 2004). In fact, Horowitz \& McConnell (2002) comment that no other economic question has been researched as much as endowment effects, but all of these are developed countries' studies, mainly in the United States (Novemsky \& Kahneman, 2005).

Revising the existing literature one may find several explanations of this "rationality anomaly":

a) Loss aversion. Kahneman and Tversky (1984) suggest that loss aversion produces that the disutility to give up an object is larger than the utility generated by its acquisition. Therefore, if giving an object away is a loss, and acquiring it is a win, then loss aversion will generate -on average- that owners would like more money to sell a good (or would perceive its lost as having a larger monetary value than they would offer and pay if they did not have it and want it. (Kahneman et al., 1990). From this perspective, the difference between the selling price and the buying price shows the presence of loss aversion (Bar-Hillel \& Neter, 1996; van Dijk \& van Knippenberg, 1998). This will produce that at the time to enter a market buyers and sellers will value goods in different ways, since both parties will focus on the losses of the transaction: buyers will focus on losing the money (to purchase the good, having a nominal and clear value) and sellers will focus on losing the good (adding a more subjective value of loss), and asking a larger price (Carmon \& Ariely, 2000).

b) Extended self. Belongings can be parts of the extended self of individuals (Belk 1988). Cars, pets, tools, garments, computers can be literally considered by consumers as "parts of themselves". Consequently, selling or losing those belongings will damage their self-images, inhibiting their willingness to give up or sell the product. At the same time, if asked, they will value more a good that are part of them, compared to goods they do not own already (they are not part of themselves). If this is the case, owners will value goods higher than no owners (Beggan, 1992; Heider, 1958). Several studies find that emotional bonding with the good increases endowment effects (Ariely \& Simonson, 2003; Carmon et al., 2003; Dhar y Wertenbroch, 2000; Strahilevitz \& 
Loewenstein, 1998; Rottenstreich \& Hsee, 2001). Another interesting mechanism will suggest that in the case of subjects that have a better image of themselves, they will probably assigned more value to their belongings than average subjects (Thorndike, 1920).

c) Market experience. Analyzing endowment effects List (2003, 2004) shows that individuals with more intense market experience (more years or numbers of transactions) are less prone to present endowment effects. Experts may become familiar with purchasing and selling of products and therefore more willing to engage in selling their possessions (Loomes et al., 2003). Additionally, experts may have a more precise idea of the "market" values of goods. In the stock market, for example, where sellers value their stocks higher than buyers, the differences in valuation are larger among individual agents than institutional agents, who trade more regularly and therefore are more "experienced", suggesting that they are less influenced by endowment effects (Furche \& Johnstone, 2006). Expert agents learn to trade based on long term values more than based on instant emotions of giving up or buying (Kahneman, 2003b).

d) Relative Bargaining Power. Owners facing strong demand for their goods, might ask for higher prices than those owners feeling weak market demand. These perceptions can also affect buyers' behavior and purchasing disposition (Mandel, 2002). The bargaining power may be affected by income; i.e, some authors suggest that lower income individuals, may have a smaller disposition to pay for a good thus affecting endowment effects (Horowitz y McConnell, 2002). Consistently, the substitution possibilities may also affect bargaining powers and endowment effects. If a particular good can be easily substituted then bargaining powers of sellers and endowment effects are lower (Hanemann, 1991; Shogren et al., 1994). On the contrary, more unique goods (e.g., tickets for a sold-out event, unique art pieces) present larger endowment effects (Chapman, 1998; Kahneman et al., 1990).

e) Origin of the endowment or possession. Several studies have shown that the assets' origin may affect agents' behavior. (e.g. Keeler et al. (1985), Arkes et al. (1995); Thaler \& Johnson (1990). For example, Thaler and Johnson (1990) show that players increase their gambling disposition when the money they use the money they won gambling. Special gifts versus meaningless items, might produce differences in endowment effects.

f) Length of ownership and sunk costs. If agents own a good for longer periods of time emotional attachment and ownership costs will increase therefore possibly increasing endowment effects. Mackenzie (1997) suggests that time, storage, and cognitive costs during ownership (i.e. sunk costs) will affect good valuation and endowment effects. These effects will grow with length of (Strahilevitz \& Loewenstein, 1998).

g) Transaction context. As suggested by psychologists and decision theorists, context always plays an important role in decision making and behavior. The level of information of the transaction contexts may then affect endowment effects. In high information contexts - when agents get very detailed explanations and information on the goods and offers- prices will move towards equilibrium (Plott \& Zeiler 2005) thus reducing endowment effects. Other particular conditions like agents' anonymity, sadness, and disgust, may increase the willingness to change, or forget, and therefore 
to sell possessions, reducing endowment effects (Plott \& Zeiler 2005, Lerner et al. 2004)

h) Good usage. Kahneman (1992) suggests that good consumption or usage may affect the endowment effect. Subjects who purchase an item for their own use will probably show a lower predisposition to exchange it or sell it than subjects who bought it for its resale (Kahneman et al., 1990; Mandel, 2002).

i) Status quo effect. Inertia and habit are important drivers of human behavior. Therefore, defaults and status quo play an important role in explaining behavior. Given the existing endowment is the status quo, this basic human condition of resisting change and preferring the actual state of things, may itself produce endowment effects (Kahneman et al., 2003b).

j) Cognitive dissonance. Agents, when making decisions (e.g. buying or selling) may face cognitive dissonance if they experience negative effects of the decision (e.g. not the right price), questioning the decision made (Festinger, 1957). As a way to reduce cognitive dissonance and feel they are making the right decision, they may overvalue their possessions when selling or undervalue goods when buying, thus developing endowment effects.

This rich theoretical and empirical literature supports the presence and provides reasons for the existence of endowment effects. Additionally, the literature suggests that endowment effects may differ across subjects and segments. This is an important reason for testing the cross cultural presence and the strength and stability of endowment effects. Hofstede (1980) and others (i.e. Fernandez et al 1997) have shown that managers and individuals in Latin America tend to be more collectivist, and have a stronger sense of power distance. Despite these cultural differences, our main hypothesis is that the drivers of endowment effects are common to all individuals, regardless of their culture, and will be stronger and override cultural effects, since they are part of psychological and biological mechanisms common in all humans, and that explain our persistently "quasi rational" or "predictably irrational" behavior (Ariely 2008, Thaler \& Sunstein 2008).

\section{EXPERIMENTAL DESIGN}

An experimental approach fits better the objectives of the study of testing the presence of endowment effects in Chile. The design of the experiment is very important to replicate in an experimental setting what happens in real life conditions. In particular, we implement the same experiment List (2004) suggests in his classical study, following an etic approach to research across cultures or nations (Olavarrieta 2001). Experimenters randomly assign each subject participating in the study to one treatment condition, which differs by only the initial endowment: $E_{\text {mug }}, E_{\text {pen }}, E_{\text {neither. }}$ Subjects in treatment Emug have (are endowed with) 1 coffee mug and subjects in treatment group Epen are endowed with 1 pen. Mugs and pens are items of similar monetary, functional, and emotional value.

The fundamental insights from the treatments come from the choices subjects make when asked if they would like to trade. In Treatment $\mathrm{E}_{\text {mug }}\left(\mathrm{E}_{\mathrm{pen}}\right)$, subjects who are 
initially endowed with a mug (pen) decide whether to trade for a pen (mug). Hence, the subject can either keep her initial endowment or trade it for the other good. Treatment $\mathrm{E}_{\text {neither }}$ has subjects simply choosing one of the two goods.

The experiment participants are 90 business students attending regular classes in a Chilean University. They participate in the study as part of the course requirements. Each participant's experience follows three steps: (1) completing a survey, (2) considering the potential trade, and (3) concluding the transaction and exit interview. In Step 1, the monitor approaches individuals and inquires about their interest in filling out a survey that would take about five minutes. If the individual agreed, the monitor explains that in return for completing the survey the subject will receive his (her) endowed good. After physically giving the subject the appropriate endowment (when applicable), the subject proceeds to fill out the survey. No time limit is imposed. In Step 2, the monitor informs the subject that he (she) has the opportunity to trade her mug (pen) for the pen (mug). In Treatment $\mathrm{E}_{\text {neither }}$ the subject is asked to choose one of the two goods. The monitor allows the subject to inspect both goods. Step 3 closes the experiment and includes an exit interview.

Some aspects of the experimental design merit further consideration. First, subjects receive the good as payment for completing the survey, and had the good in their possession while filling out the survey. Second, when performing this type of trading exercise, care should be taken to select goods of approximately equal value to avoid a result of everyone selecting one type of good. In a market pre-test, we asked forty subjects to choose one of the two items. Twenty-one choose the coffee mug, whereas nineteen chose the pen, supporting the belief that both goods - pen and mugare similar enough in value to use for a trading exercise. Third, no subject participates in more than one treatment. Fourth, the monitor works one-on-one with each subject.

Neoclassical theory and prospect theory and endowment effect literature have sharp and disparate predictions about behavior across the various endowment points. For preferences to be consistent under neoclassical theory, the proportion of subjects who trade the mug for the pen should be equal to one minus the proportion who trade the pen for the mug. Thus, if X percent of the subjects endowed with a pen keep the pen, for preferences to be Hicksian, approximately X percent of subjects endowed with a mug should trade for a pen. Similarly, for $\mathrm{E}_{\text {neither }}$ there should be independence between the point of endowment and the final entitlement.

Alternatively, the existing literature on endowment effects and prospect theory (Kahneman \& Twersky 1979) conjectures that mere ownership of a commodity will induce a kink of the value function at the point of endowment, making the proportion of subjects who opt to trade the mug for the pen lower than one minus the proportion who trade the pen for the mug. Likewise, prospect theory predicts that subjects in Treatment $\mathrm{E}_{\text {neither }}$ will opt for a mug (pen) more often than subjects initially endowed with a pen (mug).

\section{RESULTS}

Table 1 provides a summary of the trading data. In row 1 , column 1 , at the intersection of "Treatment $E_{\text {pen }}$ " and "Number of subjects choosing pen," the figure 17 indicates that that 17 subjects out of 30 (56.7\%) that were initially endowed with a pen chose to keep the pen. The figure in row 1 , column 2 , is the complement of this result indicating that 13 out of $30(43.3 \%)$ subjects opted to trade their pen for the 
coffee mug.

Row 2, column 2, at the intersection of "Treatment $\mathrm{E}_{\text {mug }}$ " and "Number of subjects choosing mug," shows that 23 subjects out of 30 (76.7\%) that were initially endowed with a mug chose to keep the mug. The figure in row 2 , column 1 , complements this result and indicates that 7 out of 30 (23.3\%) subjects opted to trade their mug for the pen.

The third column in Table 1 presents Pearson chi-square test, which examine the null hypothesis of Ho: $\mathrm{p}_{\mathrm{pen}}=\mathrm{p}_{\mathrm{mug}}=\mathrm{p}_{\text {neither; }}$ where pi are the parameters of 3 independent binomially distributed random variables, and therefore the null hypothesis tests whether there is a treatment effect. As suggested by List (2004) if the null hypothesis cannot be rejected, then evidence is in favor of neoclassical theory; rejection of the null (with the correct pi signs) provides evidence in favor of prospect theory. Overall, the results in Table 1 provide strong support for prospect theory. Pearson chi-square test (2 degrees of freedom) suggests that the null hypothesis of no treatment effect should be rejected at the $\mathrm{p}<.05$ level $\left(\mathrm{X}^{2}=7.196\right)$. Then this study results confirm that the endowment effect is not restricted to developed countries. Therefore, in Latin America the endowment effect should be included into forecasting and understanding buyer and human behaviour.

Table 1. Summary of experimental raw data

\begin{tabular}{cccc}
\hline Treatment & $\begin{array}{c}\text { Number of subjects } \\
\text { choosing pen }\end{array}$ & $\begin{array}{c}\text { Number of subjects } \\
\text { choosing mug }\end{array}$ & Pearson $\mathrm{X}^{2}$ \\
\hline $\begin{array}{c}\mathrm{E}_{\text {pen }} \\
(\mathrm{n}=30)\end{array}$ & 17 & 13 & 7.196 \\
$\mathrm{E}_{\text {mug }}$ & $(56.7 \%)$ & $(43.3 \%)$ & $(2$ d.f. $)$ \\
$(\mathrm{n}=30)$ & 7 & 23 & p-value $=.027$ \\
& $(23.3 \%)$ & $(76.7 \%)$ & \\
$\mathrm{E}_{\text {neither }}$ & 14 & 16 & \\
$(\mathrm{n}=30)$ & $(46.7 \%)$ & $(53.3 \%)$ & \\
\hline
\end{tabular}

\section{IMPLICATIONS}

Results support the hypothesis of endowment effects among Chilean subjects, thus suggesting that endowment effects might be a cross-cultural and more universal phenomenon. Therefore, endowment effects need to be considered for modeling choice, predicting behavior and designing marketing and business strategies and public policies. Endowment effects affect preference and the behavior of consumers, managers and investors behavior in Latin America. For example, Kahneman et al. (1991) have shown that individuals may have a higher tendency than predicted by rational models to keep their initial endowments, thus reducing trading volume, a key price making mechanism. Also, potential differential effects of endowment might be investigated across different Latin American nations, or segments in the Latin American market.

In marketing, Wolf, Arkes and Muhanna (2008) found empirical support for the power of touch on consumer valuation of objects. Consumers that hold products or 
items for more seconds (in the traditional mug experiment) will assign more value and will be willing to bid higher prices for the same mugs compared to consumers that were asked to hold the products for a shorter period of time. This type of behavior may support different types of actions at the marketing strategy level. For example, mixed distribution strategies, may be appropriate for web-based stores and brands, since they may benefit if they open "brick" stores to show their products, and allow consumers to touch them. Higher switching costs can be developed, if ownership and loyalty is increased in time. Then loyalty programs may have stronger effects. On the opposite side, marketers wanting the competitors' customers to switch to their brands and products may design stronger strategies to establish ownership, with products sampling, building and creating experiences for them (through events, experiential stores and websites, etc.). The relevance of launching adequate digital marketing and social media strategies is also highlighted by these findings. Social media, can increase the sense of ownership, belonging, and relational costs with brands and with brand customers, thus solidifying relationships and increasing endowment effects.

Further implications can also be derived to public policy, management, top executive behavior, and other real-life situations. In the public policy arena, as suggested by Thaler and Sunstein (2008), the importance of endowment effects, is critical for savings and financial decisions, for health care and for job and leisure decisions. How many persons are dissatisfied with their jobs but do not move on and change due to status quo biases and endowment effects.

Another important implication of the study is the need to revise human behavior theories, models and assumptions included in business curriculums (both undergraduate and graduate). Simpler economic models using completely rational assumptions for human behavior may be weak for understanding individual-level (consumers, managers) decision-making processes. The need to include decision biases and quasi rational models is clear and pending in regular business curriculums. This area of research may be very fruitful for marketing scholars, decision and management researchers, and for public policy designers, who will benefit from a more "real" and "less rational" approach to human decision making. Further research in Latin America about these issues is needed for a better understanding of the subject to strengthen business disciplines in the region and to expand our countries possibilities (Olavarrieta \& Villena 2014). Future research may expand this study and explore the conditions under which endowment effects may be stronger or weaker (type of goods or endowments, knowledge and experienced consumers, etc.). Also, these results call for a reexamination of predictions when endowment effects might be present and may magnify or override predicted behaviors both in consumption, work motivation and managerial decision-making situations.

\section{REFERENCES}

Allais, M. (1953). Le comportament de l'homme rationnel devant le risqué, critique des postulats et axioms de l'ecole americaine, Econometrica, 21, 503-546

Arkes, H., C. Joyner, M. Pezzo, J. Nash, K. Jacobs \& E. Stone. (1995). The psychology of windfall gains, Organizational Behavior and Human Decision Processes, 59, 331-347 
Ariely, D. (2008), Predictably Irrational: The Hidden Forces that Shape our Decisions, New York: Harper Collins.

Ariely, D. \& I. Simonson (2003). Buying, Bidding, Playing, or Competing? Value Assessment ad Decision Dynamics in Online Auctions, Journal of Consumer Psychology, 13(1), 113-123

Barberis, N., M. Huang \& T. Santos (2001). Prospect Theory and asset prices, Quarterly Journal of Economics, 116(1), 1-53

Bar-Hillel, Maya \& Efrat Neter (1996). Why are people reluctant to exchange lottery tickets?, Journal of Personality and Social Psychology, 70 (January), 17-27

Beggan, J. (1992). On the social nature of non-social perception: The mere ownership effect, Journal of Personality and Social Psychology, 62, 229-237

Belk, R. W. (1988). Possessions and the Extended Self. Journal of Consumer Research, 15 (2), 139-168.

Bernoulli, D. (1738). Specimen Theoriae Novae de Mensura Sortis. En Commentarii Academiae Scientarium Imperialis Petropolitanae, Tomus V, 175-192. Traducido por L. Sommer (1954) como Exposition of a new theory of the measurement of risk, Econometrica, 22, 23-26

Camerer, C. (2000), Prospect Theory in the wild in Choices, Values and Frames. Daniel Kahneman and Amos Tversky (Eds.), Cambridge: Cambridge University Press, 288300.

Carmon, Z. \& Ariely, D. (2000), Focusing on the forgone: how value can appear so different to buyers and sellers, Journal of Consumer Research, 27, 360-370

Carmon, Z., K. Wertenbroch, \& M. Zeelenberg (2003). Option attachment: when deliberating makes choosing feel like losing, Journal of Consumer Research, 30 (June), 15-29

Chapman, G. (1998). Similarity and Reluctance to Trade, Journal of Behavioral Decision Making, 11(March), 47-58

Dhar, R. \& K. Wertenbroch (2000). Consumer choice between hedonic and utilitarian goods, Journal of Marketing Research, 37 (February), 60-71

Fastoso, F. \& Whitelock, J. (2011).Why is so little marketing research on Latin America published in high quality journals and what can we do about it? : Lessons from a Delphi study of authors who have succeeded, International Marketing Review, 28 (4), 435 - 449

Fernández, D., D. Carlson, L. Stepina \& J. Nicholson (1997), Hofstede's Country Classification, 25 years later, The Journal of Social Psychology, Washington, 137, 4355. 
Festinger, L. (1957). A Theory of Cognitive Dissonance. Evanston, IL: Row, Perterson \& Company.

Furche, A. \& D. Johnstone. (2006). Evidence of the endowment effect in stock market order placement, Journal of Behavioral Finance, 7(3), 145-154

Hanemann, W. (1991). Willingness to pay and willingness to accept: how much can they differ?, American Economic Review, 81(3), 635-647

Heider, F. (1958). The psychology of interpersonal relations. New York: Wiley.

Hitsch, G. J, Hortaccsu, A., \& Dan Ariely (2010). What makes you click? Mate preferences in online dating. Quantitative Marketing and Economics 8 (4), 393-427.

Hofstede, G. (1980), Culture's Consequences: International Differences in work-related values, Beverly Hills, CA: Sage Publications.

Horowitz, J. \& K. McConnell (2002). A review of WTA/WTP Studies, Journal of Environmental Economics and Management, 44, 426-447

Huck, S., G. Kirchsteiger \& J. Oechssler (2005). Learning to like what you have Explaining the endowment effect, Economic Journal, 115 (July), 689-702

Kahneman, D. (2003b). Maps of Bounded Rationality: Psychology for Behavioral Economics, American Economic Review, 93 (5), 1449-1475

Kahneman, D. (2003a). A Psychological Perspective on Economics, AEA Papers and Proceedings, 93 (2), 162-168

Kahneman, D. (1992). Reference Points, Anchors, Norms, and Mixed Feelings, Organizational Behavior \& Human Decision Processes, 51 (2), 296-312.

Kahneman, D. \& Krueger, A. (2006). Developments in the measurement of subjective well-being, Journal of Economic Perspectives, 20 (1), 3-24

Kahneman, D. \& Tversky, A. (1984). Choices, values and frames. American Psychologist, 39, 341-350.

Kahneman, D. \& Tversky, A. (1979), Prospect Theory: An Analysis of Decision under Risk, Econometrica, 47 (2), 263-292.

Kahneman, D. Knetsch, J.L. \& R. H. Thaler (1991), Anomalies: the endowment effect, loss aversion, and status quo bias, Journal of Economic perspectives, 5 (1), 193-206.

Kahneman, D., Knetsch, J.L. \& R.H. Thaler (1990), Experimental test of endowment effect and the Coase theorem, Journal of Political Economy, 98 (6), 1325-1348.

Keeler, J., W. James \& M. Abdel-Ghany (1985). The relative size of windfall income and the permanent income hypothesis, Journal of Business and Economic Statistics, 3, 209-215 
Knetsch, J. L. (1989). The endowment effect and evidence of non-reversible indifferences curves, American Economic review, 79 (5), 1277-1284

Knetsch, J.L. \& Sinden, J.A. (1984), Willingness to pay and compensation demanded: experimental evidence of an unexpected disparity in measures in value, Quarterly Journal of Economics, 99 (3), 507-521

Lerner, J., D. Small \& G. Loewenstein (2004). Heart Strings and Purse Strings. Carryover Effects of Emotions on Economic Decisions, Psychological Science, 15(5), 337-341

Levin, I., J. Schereiber, M. Lauriola \& G. Gaeth (2002). A tale of two pizzas, Marketing Letters, 13 (November), 335-345

List, J. (2003). Does market experience eliminate market anomalies?, Quarterly Journal of Economics, 118(1), 41-71

List, J. (2004). Neoclassical Theory versus Prospect Theory: Evidence from the Marketplace. Econometrica, 72 (2), 615-625

Loomes, G., C. Starmer \& R. Sugden (2003). Do anomalies disappear in repeated markets?, Economic Journal, 113 (March), 153-166

Mackenzie, C. (1997). Where are the motives? A problem with evidence in the work of Richard Thaler, Journal of Economic Psychology, 18 (1), 123-135

Maddux, W.M., Yang, H., Falk, C., Adam, H., Adair, W., Endo, Y., Carmon, Z., \& S. Heine (2010). For whom is parting with possessions more painful? Cultural differences in the endowment effect. Psychological Science, 30 (December), 15-29: DOI: $10.1177 / 0956797610388818$

Mandel, D. (2002). Beyond mere ownership: transaction demand as a moderator of the endowment effect, Organizational Behavior and Human Decision Processes, 88, 737-747

Manzur, E., Olavarrieta, S., Hidalgo, P. \& Farías, P. Endowment Effect in Latin America: An Experiment (2014). SSRN: https://ssrn.com/abstract=2620975 or http://dx.doi. org/10.2139/ssrn.2620975

Markowitz, H. (1952). The utility of wealth, Journal of Political Economy, 60, 151-158

McDaniels, T. (1992). Reference points, loss aversion, and contingent values for auto safety, Journal of Risk and Uncertainty, 5 (2), 187-200

Morrison, G. (1998). Understanding the disparity between WTP and WTA: endowment effect, substitutability, or imprecise preferences?, Economics Letters, 59(2), 189194

Nayakankuppam, D. \& H. Mishra. (2005). The endowment effect: Rose-Tinted and Dark-Tinted Glasses, Journal of Consumer Research, 32, 390-395 
Nicholls-Nixon, C. L.; Castilla, J.A.D.; García, J. S. \& M. R. Pesqera, (2011) Latin American Management Research: Review, Synthesis and Extension. Journal of Management, 37 (4), 1178-1227. 2011.

Olavarrieta, S. (2001). Aspectos Metodológicos en la Investigación Cross-Cultural. Academia-Revista Latinoamericana de Administración, 26, 55-78.

Olavarrieta, S. \& M. Villena (2014) Innovation and Business Research in Latin America: An Overview. Journal of Business Research 67 (4), 489-497. 2014.

Novemsky, N. \& D. Kahneman (2005). The boundaries of loss aversion, Journal of Marketing Research, 42 (May), 119-128

Plott, C. \& K. Zeiler (2005). The Willingness to Pay-Willingness to Accept Gap, the "Endowment Effect," Subject misconceptions, and experimental procedures for eliciting valuations, American Economic Review, 95 (3), 530-545

Rottenstreich, Y. \& C. Hsee (2001). Money, Kisses, and Electric Shocks: On the Affective Psychology of Risk, Psychological Science, 12(3), 185-190

Ryan, M. \& C. Ubach (2003). Testing for an experience endowment effect in health care, Applied Economics Letters, 10, 407-410

Sen, S. \& J. Johnson (1997). Mere-Possession effects without possession in Consumer Choice, Journal of Consumer Research, 24(1), 105-117

Shogren, J., Shin, S., Hayes, D. \& Kliebenstein, J. (1994).Resolving differences in willingness to pay and willingness to accept, American Economic Review, 84(1), $255-270$

Simonson, I. \& A. Drolet (2004). Anchoring Effects on Consumers' Willingness to-Pay and Willingness-to-Accept, Journal of Consumer Research, 31(December), 681-690

Strahilevitz, M. \& G. Loewenstein (1998). The effect of ownership history on the valuation of objects, Journal of Consumer Research, 25(3), 276-289

Thaler, R. (1987), The psychology of choice and the assumptions of economics, New York: Cambridge University Press.

Thaler, R. (1980), Toward a positive theory of consumer choice, Journal of Economic Behavior and Organization, Vol. 1, 39-60

Thaler, R. \& E. Johnson (1990). Gambling with the house money and trying to break even: the effects of prior outcomes on risky choice, Management Science, 36, 643660 
Thaler, R. \& Cass R. Sunstein (2008), Nudge:Improving Decisions about Health, Wealth and Happiness, New York: Penguin Books.

Thorndike, R. (1920). Intelligence and Its Uses, Harper's Magazine, 140, 227-335.

Tom, G., C. Nelson, T. Srzentic \& R. King. (2007). Mere exposure and the endowment effect on consumer decision making, Journal of Psychology, 141(2), 117-125

Van Dijk, E. \& D. van Knippenberg (1998). Trading wine: on the endowment effect, loss aversion, and the comparability of consumer goods, Journal of Economic Psychology, 19(4), 485-495

Zhang, Y. \& A. Fishbach (2005). The role of anticipated emotions in the endowment effect, Journal of Consumer Psychology, 15(4), 316-324 